\title{
Historein
}

Vol 14, No 1 (2014)

On the Edge of History and Philosophy

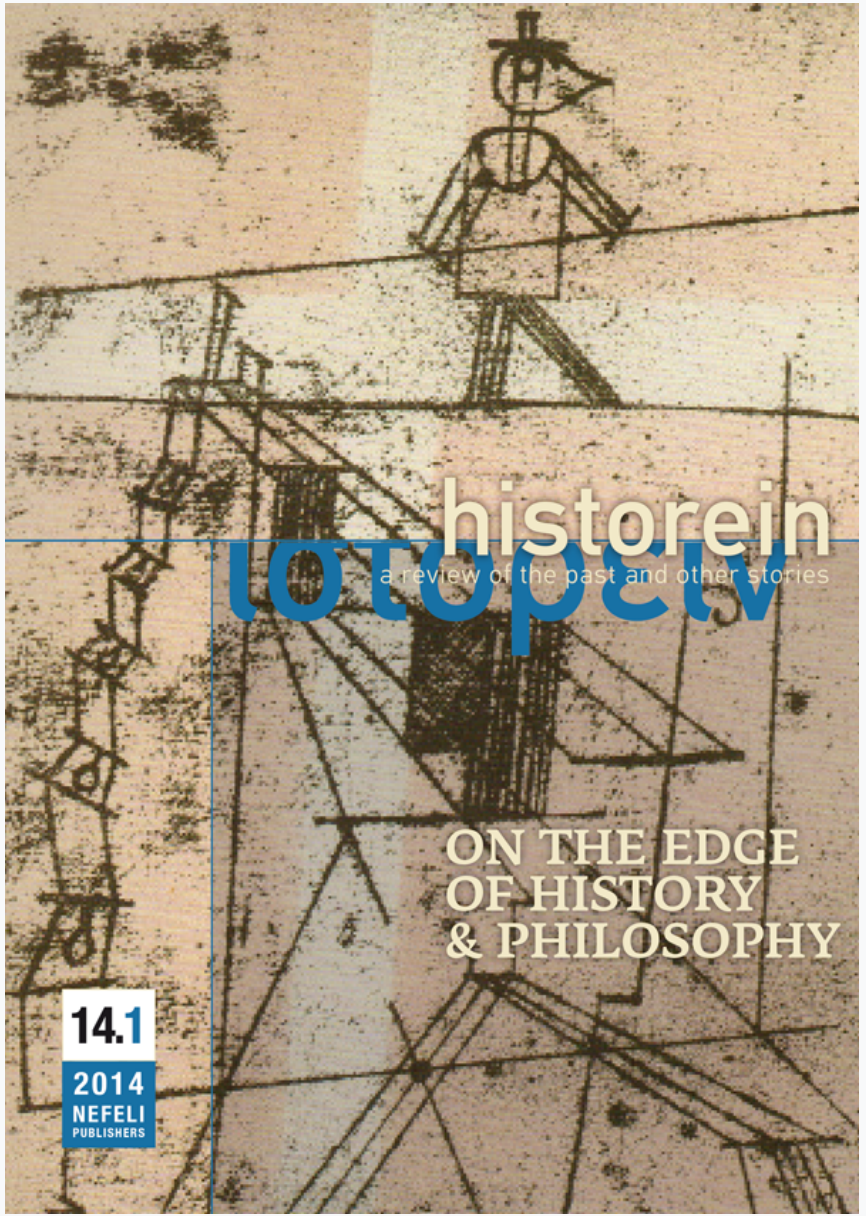

\section{Introduction: On the Edge of History and Philosophy}

Editorial Committee

doi: $10.12681 /$ historein.284

Copyright ( 9 2014, Editorial Committee

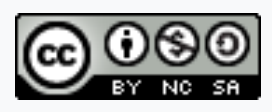

This work is licensed under a Creative Commons Attribution-NonCommercialShareAlike 4.0.

\section{To cite this article:}

Committee, E. (2014). Introduction: On the Edge of History and Philosophy. Historein, 14(1), 5-6. https://doi.org/10.12681/historein.284 


\section{On the edge of history and philosophy}

This issue includes three articles on memory and the philosophy of history, as well as a discussion on history and philosophy. The first piece discusses, in philosophical terms, the prevalence in recent decades of a culture of memory in western societies. The following articles concentrate on the functions of memory that derive from testimonies of violent experiences, such as the crimes committed during the last Argentinean dictatorship and the medical experiments performed by the Nazis.

Maria Inés Mudrovcic interprets "the explosion of memory" that dominates western societies today, in the absence of the likelihood of any meaningful future opening up new horizons and expectations. She analyses the different meanings of the past in early modern and modern times, after the occurrence of various historical events that generated a complete break with the past, creating different political and historical identities. In her discussion of the pivotal moments of the French Revolution and the collapse of the Soviet Union, Mudrovcic illuminates both the different perceptions of time these events created and the notions about the uniformity of human nature they imply. She claims that it was because twentieth-century catastrophes did not break the political order of the modern secular state, the historical subject of modernity, that an order of time which draws on the past read as "memory" became dominant.

\section{Introduction}

In her article, Cecilia Macón employs an innovative approach by focusing on metatesti-

monies (testimonies in which witnesses express their views and feelings about testifying at trial) of victims of sexual violence during the last Argentinean dictatorship. These powerful testimonies by former female "disappeared" detainees were collected in the last decade. The article stresses the performativity of "negative" affects, such as shame and the elucidation of remembering as a productive and empowering process, to illustrate the historical, philosophical and political contribution made by the affective turn. Underlining the distinction between victimisation and victimhood, the author demonstrates how emotions contribute to alternative ways of construing the public sphere, while moving beyond the public/private and victimhood/agency dichotomies.

Marius Turda focuses on the memoirs of Miklós Nyiszli, a Jewish doctor and Auschwitz prisoner, who was forced to take part in the medical experiments conducted by Josef Mengele. Turda discusses the complexity of Nyiszli's testimony in terms of its dual function, i.e. as bearing witness to 
the medical experiments and extermination of Jews in Auschwitz and as an understanding of the meaning of Nazi science and of his own role as a doctor, participant and witness. He is most interested in analysing the text within the framework of Primo Levi's "grey zone" and also casts light on Nyiszli's deep insight into Mengele's racist worldview and the criminal medical practices that informed German science during the Third Reich.

\section{Crossing the borders of history and philosophy}

This issue also presents a discussion of Chris Lorenz' 2009 book Przekraczanie granic: eseje z filozofii historii i teorii historiografii [Bordercrossings: essays on the philosophy of history and theory of historiography] which was held in Poznań, on 19 February 2010. The book is an example of critical analysis of narrativist approaches to the philosophy and methodology of history. The dialogue was organized by Prof Krzysztof Brzechczyn (Adam Mickiewicz University), and sponsored by the Poznań chapter of the Polish Philosophical Society, the Department of Philosophy and the Faculty of Social Sciences of Adam Mickiewicz University. In addition to Lorenz and Brzechczyn, the other participants in the discussion were Hayden White, Ewa Domańska, Aviezer Tucker and Monika Bobako. 